\title{
PEMBUATAN SUSU TEMPE KAJIAN PENGARUH LAMA FERMENTASI TEMPE DAN PENGGUNAAN Carboxymethyl cellulose (CMC)
}

\author{
Oleh: \\ Hapsari Titi $\mathbf{P}^{1)}$, M. Saihullah ${ }^{2)}$ \\ 2) Tenaga Pengajar Fakultas Pertanian Universitas Yudharta Pasuruan \\ 1) Alumni Fakultas Pertanian Univerasitas Yudharta Pasuruan
}

\begin{abstract}
Abstrak
Tujuan penelitian adalah mengetahui kombinasi perlakuan lama fermentasi tempe dan konsentrasi penambahan carboxymethy cellulose (CMC) terhadap kualitas susu tempe. Penelitian ini menggunakan Rancangan Acak Kelompok (RAK) Faktorial, terdiri dari 2 faktor: Faktor 1 :. lama fermentasi pembuatan tempe, terdiri dari tiga level yaitu 36, 48 dan 60 jam. Faktor 2 : konsentrasi penambahan carboxymethyl cellulose (CMC) dengan konsentrasi: $0,25 \%$ dan $0,5 \%$. Berdasarkan hasil penelitian perlakuan kombinasi lama fermentasi tempe dan konsentrasi penambahan carboximethyl cellulose (CMC) berpengaruh nyata terhadap TPT ( total padatan terlarut), $\mathrm{pH}$ dan organoleptik rasa, warna dan aroma susu tempe. Perlakuan terbaik adalah kombinasi lama fermentasi tempe 36 jam dan konsentrasi penambahan carboximethylcellulose (CMC) $0,25 \%$ yaitu kadar protein $1,34 \%$; total padatan terlarut 9,67 (brix), pH 6,72 ; organoleptik rasa 4,50 (suka); warna 4,50 (suka) dan aroma 4,70 (suka).
\end{abstract}

Kata kunci : susu tempe, lama fermentasi tempe, carboximethyl cellulose (CMC) 


\begin{abstract}
The objective of the research is to study the combination of treatments on the time period of tempe fermentation and concentrate of carboxymethyl cellulose (CMC) as stabilizer compared to the quality of tempe milk. This study uses Randomized Block Design Faktorial, which consists of two factors. The first factor is tempe fermentation period which consists of three levels i.e. 36 hours, 48 hours, and 60 hours. The second factor is addition of carboximethyl cellulose (CMC) concentration which consists of two levels, i.e. $0,25 \%$ and $0,5 \%$. The research results reveal that the combination of treatments on the time period of tempe fermentation and addition of carboxymethyl cellulose (CMC) as stabilizer provide significant effect to $\mathrm{pH}$, total soluble solids and organoleptic of taste, color and flavor of tempe milk. The best result characterized tempe milk by protein content $1,34 \%$; total soluble solids 9,67 (brix); $\mathrm{pH} \mathrm{6,72;} \mathrm{organoleptic} \mathrm{of} \mathrm{taste} \mathrm{4,50}$ (like), color 4,50 (like) and flavor 4,70 (like), produced by the 48 hour fermentation period and concentrate of carboxymethyl cellulose (CMC) of 0,25\% Carboxymethyl cellulose (CMC).
\end{abstract}

Key words : tempe milk, time period of fermentation tempe, carboxymethyl cellulose $(\mathrm{CMC})$.

PENDAHULUAN

Tempe adalah makanan dari kacang-kacangan yang dibuat dari proses fermentasi kedelai menggunakan kapang Rhizopus (ragi tempe). Proses fermentasi meyebabkan kedelai terikat dan tertutup seluruhnya menjadi bentuk yang kompak berwarna putih (Buckle K.A., Edwards, Fleet and Wootton (1982) dan Anonim (2008)). Tempe merupakan makanan tradisional Indonesia yang dikonsumsi oleh semua lapisan masyarakat, dan mengandung komponen-komponen gizi tinggi, seperti protein dan vitamin $B$, bahkan tempe diketahui mengandung senyawa antioksidan (Kasmidjo, 1996).

Tempe memiliki daya simpannya rendah dan mudah rusak. Tempe dapat disimpan segar pada suhu ruang hanya bertahan dua hari sedangkan penyimpanan suhu rendah bertahan satu minggu (Widowati, S.,Yuniar, M.E. Christina dan R. Holinesti, 2004). Dalam upaya peningkatan masa simpan, nilai tambah, dan sifat 
organoleptik tempe perlu dilakukan upaya diversifikasi pengolahan tempe, salah satunya pembuatan susu tempe.

Susu tempe merupakan produk hasil ekstraksi tempe dengan air sehingga diperoleh larutan dengan komponen padatan terlarut. Susu tempe adalah salah satu produk generasi kedua tempe selain tepung tempe, bubur bayi, susu tempe, biskuit, es krim, burger, sosis dan produk lain yang tidak lagi mempunyai bentuk khas tempe. Kini produk tempe telah berkembang sampai tiga generasi. Tempe generasi kedua meliputi tepung tempe, bubur bayi, susu tempe, biskuit, es krim, burger, sosis dan produk lain yang tidak lagi mempunyai bentuk khas tempe (Widowati, 2005). Menurut Susanto, T., S. Meita, dan W. Eni (1997) prinsip pembuatan sari tempe adalah ekstraksi tempe dengan air melalui tahap pembuatan yaitu pemotongan bentuk dadu, pengukusan 3 menit, penambahan air mendidih, penggilingan, penyaringan, penambahan bahan tambahan pangan (gula, garam, perisa, penstabil) dan pemanasan pada suhu $90^{\circ} \mathrm{C}$. Susu tempe mempunyai kadar protein $2.5 \%$.

Susu tempe yang dihasilkan dipengaruhi oleh proses fermentasi tempe. Menurut (Kasmidjo, 1996) selama periode kegiatan fermentasi, menyebabkan perubahan karakteristik keseluruhan bahan dari kedelai menjadi tempe. Nouts, M. J. R., dan J. L. Kiers. (2005) menyatakan proses inkubasi tempe berlangsung pada $24-36$ jam suhu $30^{\circ} \mathrm{C}$ atau $48-$ 72 jam suhu $25^{\circ} \mathrm{C}$. Pada proses pembuatan susu tempe, perlu ditambahkan bahan penstabil untuk menghasilkan susu tempe yang berkualitas. Dalam bukunya Astawan (2009) menyatakan pada fungsi bahan penstabil adalah mencegah pengendapan pada proses pembuatan susu kedelai. Beberapa bahan penstabil dapat digunakan pada susu dari kedelai, diantaranya adalah bahan penstabil carboxymethyl cellulose (CMC). Oleh karena itu, pada pembuatan susu tempe pada penelitian ini perlu penambahan bahan penstabil carboxymethyl cellulose (CMC), sehingga diharapkan dapat menghasilkan susu tempe yang berkualitas baik. Tujuan penelitian adalah mengetahui kombinasi perlakuan lama fermentasi tempe dan konsentrasi penambahan carboxymethyl cellulose (CMC) terhadap kualitas susu tempe.

\section{METODOLOGI}

\section{Bahan dan Alat}

Bahan penelitian pembuatan susu tempe adalah kedelai, ragi tempe, bahan penstabil (CMC), 
gula, air Bahan lainnya adalah bahan kimia untuk analisis bersifat pro analisis.

Alat penelitian pada pembuatan susu tempe adalah blender, pisau, filter dan kain saring, botol yang sudah steril, dandang dan baskom, sendok, kompor, gelas ukur, timbangan.

\section{Rancangan Percobaan}

Penelitian ini menggunakan rancangan acak kelompok (RAK) faktorial dimana terdiri dari 2 faktor. Faktor 1(A) : Lama fermentasi tempe, terdiri dari tiga level yaitu 36, 48 dan 60 jam. Faktor 2 (B): $\quad$ konsentrasi penambahan carboxymethyl cellulose (CMC) yaitu $0,25 \%$ dan $0,5 \%$. Terdapat 6 perlakuan kombinasi yang diulang sebanyak tiga kali dengan tahap sebagai berikut:

1. Lama fermentasi 36 jam, konsentrasi penambahan carboxymethyl cellulose (CMC) $0,25 \%$ (A1B1)

2. Lama fermentasi 36 jam konsentrasi penambahan carboxymethyl cellulose (CMC) $0,5 \%(\mathrm{~A} 1 \mathrm{~B} 2)$

3. Lama fermentasi 48 jam, konsentrasi penambahan carboxymethyl cellulose (CMC) $0,25 \%$ (A2B1)

4. Lama fermentasi 48 jam, konsentrasi penambahan
carboxymethyl
cellulose
(CMC) $0,5 \%$ (A2B2)

5. Lama fermentasi 60 jam, konsentrasi

penambahan carboxymethyl cellulose (CMC)0,25\% (A3B1)
6. Lama fermentasi
konsentrasi
60 jam carboxymethyl cellulose (CMC) $0,5 \%(\mathrm{~A} 3 \mathrm{~B} 2)$

\section{Pelaksanaan Penelitian Pembuatan Tempe}

Kedelai sebanyak $1 \mathrm{~kg}$ yang sudah disortir kemudian dilakukan pengukusan pertama selama 30 menit suhu $80-100^{\circ} \mathrm{C}$. Tempe diangkat dan dikupas dengan mesin penggiling untuk menghilangkan kulit ari. Kedelai kupas direndam selama 12 jam, dicuci dan dikukus kembali pada suhu $80-100^{\circ} \mathrm{C}$. Kedelai diangkat dan didinginkan pada tampah. Dilakukan peragian dengan perbandingan 1gram ragi: 1 $\mathrm{kg}$ kedelai. Tahap akhir kedelai diratakan dan difermentasi selama 36 jam, 48 jam dan 60 jam.

\section{Pembuatan susu tempe \\ Tempe dengan}

lama fermentasi berbeda (36 jam, 48 jam dan 60 jam) dipotong dadu seukuran $2 \mathrm{~cm}^{2}$. Potongan tempe diblansir pada suhu 80-100 ${ }^{\circ} \mathrm{C}$ selama 10 menit. Tempe ditiriskan, dan penggilingan dengan ditambahkan air. Larutan tempe 
disaring dengan dua kali memberikan perpengaruh nyata penyaringan pertama dengan pada perlakuan maka dilanjutkan saringan biasa dan kedua disaring dengan Uji Beda Nyata Terkecil dengan kain kasa bersih sehingga diperoleh sari /susu tempe. Susu tempe ditambahkan bahan penstabil CMC $(0,25 \%$ dan $0,5 \%)$ dan gula, selanjutnya dipanaskan suhu $90^{\circ} \mathrm{C} 5$ menit. Susu tempe disaring kembali dan dimasukkan dalam botol steril, disimpan dalam lemari pendingin.

\section{Pengamatan}

\section{Untuk}

mengetahui

karakteristik kimia, fisika dan organoleptik maka dilakukan analisa yaitu analisa kadar protein (AOAC, 1990 ), pH (AOAC, 1990), total padatan terlarut (TPT) dan organoleptik hedonik (kesukaan) terhadap rasa, warna dan aroma (Rahayu, W 1991).

\section{Analisis data}

Data hasil pengamatan kadar protein, TPT dan $\mathrm{pH}$ dilakukan analisis ragam ANOVA, apabila dari hasil analisis ragam

(BNT), untuk mengetahui perbedaan antar perlakuan.

Organoleptik kesukaan rasa, warna, dan aroma dilakukan analisis ragam dengan metode Friedman dan jika terdapat perbedaan antar perlakuan dilanjutkan dengan uji lanjut Friedman termodifikasi untuk mengetahui perlakuan mana yang berbeda.

\section{HASIL DAN PEMBAHASAN Kadar Protein}

Berdasarkan analisa kadar potein tehadap susu tempe diperoleh rata- rata kadar protein berkisar antara 1,03\% sampai 1,50 $\%$. Analisa ragam menunjukkan kombinasi perlakuan lama fermentasi tempe dan konsentrasi penambahan carboxymethyl cellulose (CMC) tidak berpengaruh nyata terhadap kadar protein susu tempe. 


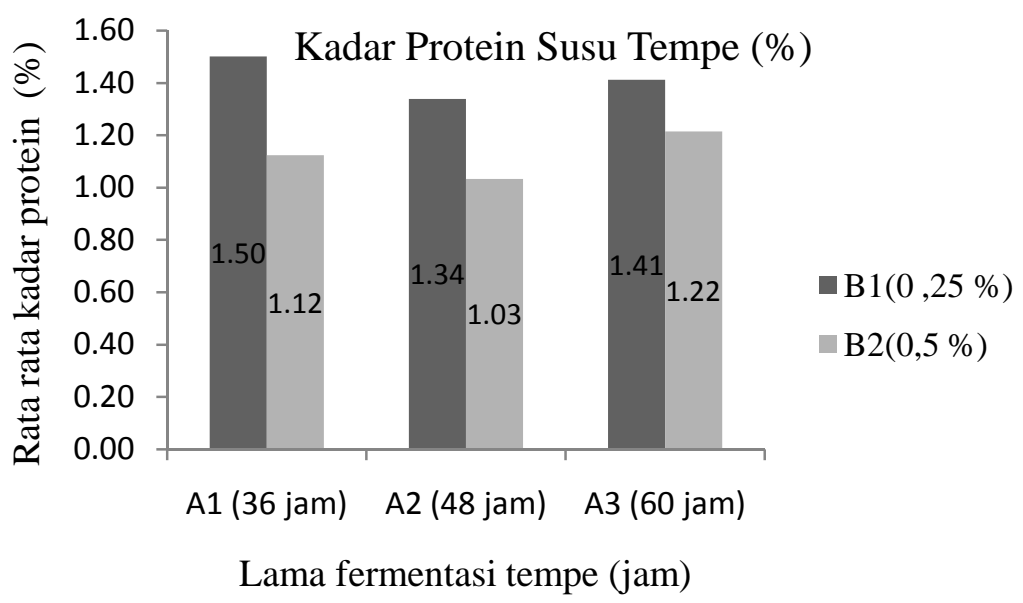

Keterangan

$\mathrm{B} 1=$ konsentrasi penambahan carboxymethyl cellulose $(\mathrm{CMC}) 0,25 \%$

$\mathrm{B} 2=$ konsentrasi penambahan carboxymethyl cellulose $(\mathrm{CMC}) \quad 0,5 \%$

\section{Gambar 1. Rata-rata Kadar Protein Kombinasi Lama Fermentasi Tempe dan Konsentrasi Penambahan Carboxymethyl cellulose (CMC)}

Kombinasi perlakuan lama fermentasi tempe dan konsentrasi penambahan carboxymethyl cellulose (CMC) tidak berpengaruh nyata terhadap kadar protein susu tempe. Pengukuran protein yang menggunakan metode Kjeidhal dinyatakan dengan mengukur kadar N (\%) dalam susu tempe. Kandungan protein yang dinyatakan sebagai kadar total nitrogen tidak berubah selama fermentasi dan penambahan carboxymethyl cellulose (CMC).
Menurut De Reu, J.C., Ten Wolde, R.M., De Groot, J., Nouts, M. J. R., Rombouts, F. M. And Gruppen, H. (1995) proses fermentasi tidak merubah total kadar nitrogen pada tempe.

\section{Total Padatan Terlarut (TPT)}

Berdasarkan analisa TPT tehadap susu tempe diperoleh ratarata total padatan terlarut berkisar antara 7.67 brix sampai 10.33 brix. Berdasarkan analisa ragam padatan terlarut menunjukkan adanya pengaruh nyata akibat kombinasi 
perlakuan lama fermentasi tempe carboxymethyl cellulose (CMC) dan konsentrasi penambahan terhadap susu tempe.

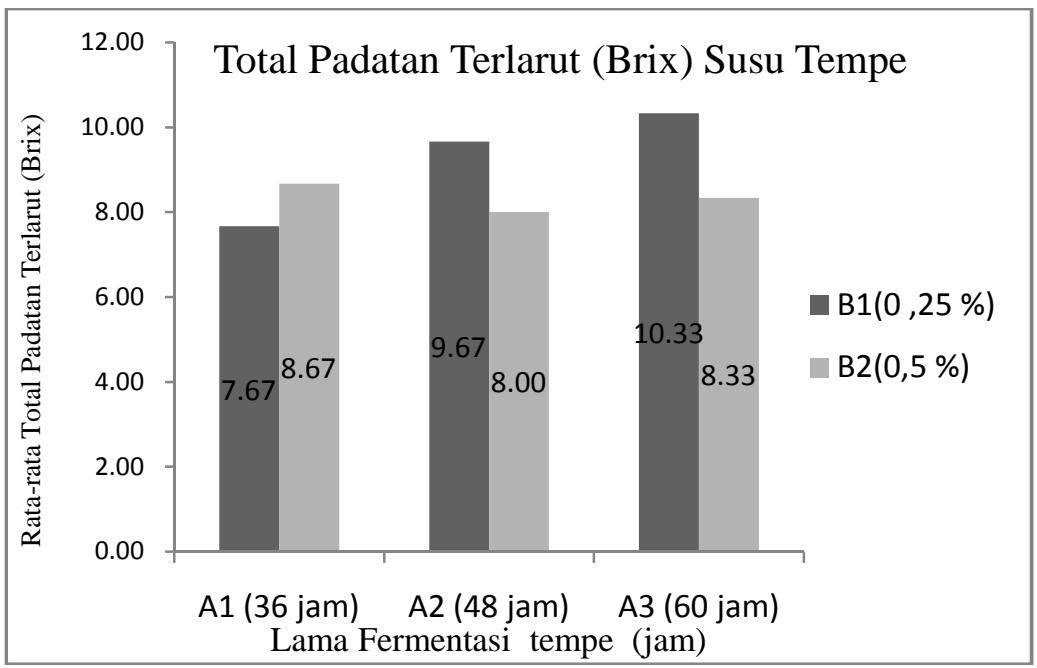

Keterangan

$\mathrm{B} 1=$ konsentrasi penambahan carboxymethyl cellulose $(\mathrm{CMC})$ 0,25\% $\mathrm{B} 2=$ konsentrasi penambahan carboxymethyl cellulose $(\mathrm{CMC}) \quad 0,5 \%$

\section{Gambar 2. Rata-rata Total Padatan Terlarut Kombinasi Lama Fermentasi Tempe dan Konsentrasi Penambahan Carboxymethyl cellulose (CMC)}

Tabel 1. menyajikan uji meningkatnya konsentrasi bahan BNT $(\alpha=0,05)$ bahwa perlakuan penstabil CMC dapat menurunkan lama fermentasi tempe 60 jam dan rata-rata kadar TPT susu tempe. konsentrasi penambahan Konsentrasi CMC 0,5\% secara carboxymethyl cellulose (CMC) umum menurunkan kadar total $0.25 \%$ menghasilkan total padatan padatan terlarut pada lama terlarut (TPT) tertinggi dan fermentasi susu yang berbeda pada berbeda nyata dari perlakuan yang susu tempe yang dihasilkan. lain. Dari hasil penelitian dengan 
Tabel 1. Rata-rata Total Padatan Terlarut Susu Tempe Kombinasi Lama Fermentasi Tempe dan Konsentrasi Penambahan Carboxymethyl cellulose (CMC)

\begin{tabular}{|c|c|c|}
\hline $\begin{array}{c}\text { Perlakuan Lama Fermentasai Tempe } \\
\text { (jam) dan Konsentrasi CMC (\%) }\end{array}$ & $\begin{array}{c}\text { Rata-Rata TPT } \\
\text { (Brix) }\end{array}$ & Notasi \\
\hline 36 jam, 0,25\% & 7,667 & $\mathrm{a}$ \\
36 jam, 0,5\% & 8,667 & $\mathrm{~d}$ \\
48 jam, 0,25\% & 9,667 & $\mathrm{e}$ \\
48 jam, 0,5\% & 8,000 & $\mathrm{~b}$ \\
60 jam, 0,25\% & 10,333 & $\mathrm{f}$ \\
60 jam, 0,5\% & 8,333 & $\mathrm{c}$ \\
\hline \multicolumn{2}{|c|}{ BNT 5\% } & 0,313136 \\
\hline
\end{tabular}

Keterangan : Angka yang diikuti huruf yang sama, tidak berbeda nyata pada BNT 5\%

Semakin lama fermentasi tempe maka akan semakin tinggi padatan terlarut pada susu tempe. Selama fermentasi tempe berlangsung, Rhizopus spp menghasilkan berbagai enzim yang menghidrolisis komponen kimia kompleks kedelai menghasilkan komponen-komponen sederhana. memiliki nilai cerna amat tinggi. Menurut De Reu, J.C., et. al. (1995) serta penelitian Nouts, M. J. R., dan J. L. Kiers. (2005) bahwa selama periode fermentasi tempe, Rhizopus menghasilkan enzim karbohidrase, lipase, protease, phytase yang menghidrolisis komponen kimia. Enzim tersebut memecah makromolekul menjadi komponen yang mempunyai berat molekul
(BM) rendah, dinding sel dan komponen dalam sel sebagian larut. Berbagai macam polisakarida mempunyai komponen berat molekul tinggi larut dibebaskan oleh degradasi enzim. Perubahan juga terjadi atas kadar protein terlarut dan terjadi peningkatan kadar asam amino bebas dalam bahan

\section{pH}

Berdasarkan analisa $\mathrm{pH}$ tehadap susu tempe diperoleh rata- rata $\mathrm{pH}$ berkisar antara 6,540 sampai 6,767. Berdasarkan analisa ragam menunjukkan adanya pengaruh sangat nyata pada perlakuan kombinasi lama fermentasi tempe dan konsentrasi penambahan carboxymethyl cellulose (CMC) 
pada pH susu tempe. Gambar 3 menunjukkan bahwa semakin lama fermentasi tempe maka $\mathrm{pH}$ susu tempe semakin tinggi. Kombinasi perlakuan lama fermentasi tempe 60 jam dan konsentrasi penambahan carboxymethyl $\begin{array}{lll}\text { cellulose } & \text { (CMC) } & 0.5 \%\end{array}$ menghasilkan $\mathrm{pH}$ susu tertinggi. Sedangkan kombinasi perlakuan lama fermentasi tempe selama 36 jam dan konsentrasi penambahan carboxymethyl cellulose (CMC) $0.25 \%$ menghasilkan $\mathrm{pH}$ yang rendah.

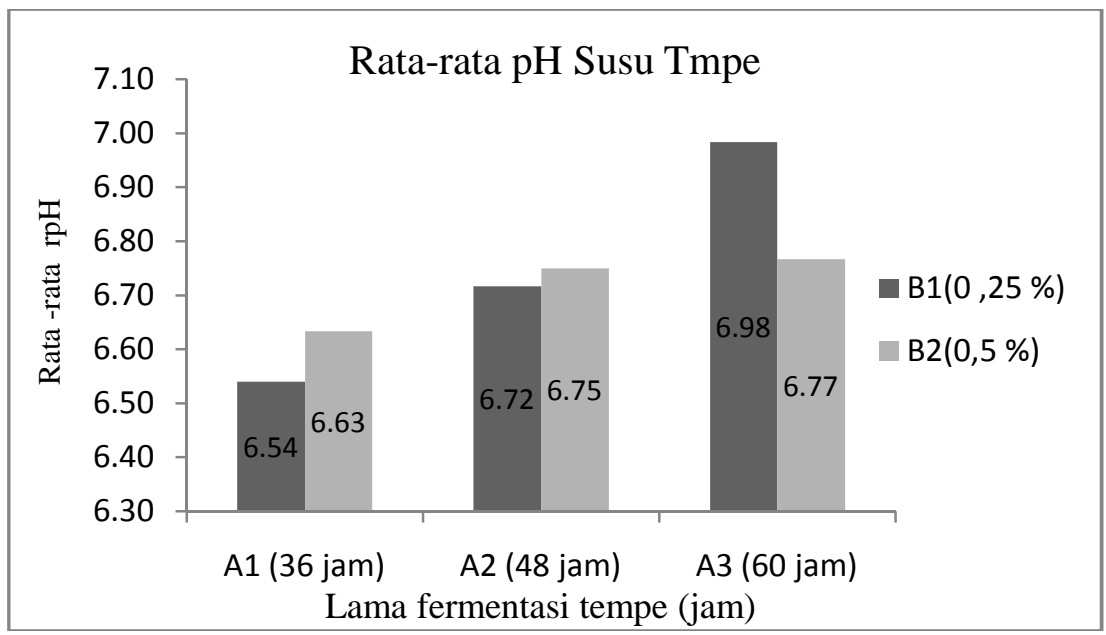

Keterangan

B1 = konsentrasi penambahan carboxymethyl cellulose (CMC) $0,25 \%$

$\mathrm{B} 2=$ konsentrasi penambahan carboxymethyl cellulose $(\mathrm{CMC}) \quad 0,5 \%$

\section{Gambar 3. Rata-rata pH Akibat Perlakuan Kombinasi Fermentasi Tempe dan Konsentrasi Penambahan carboxymethyl cellulose (CMC)}

Tabel 3 menyajikan uji BNT $(\alpha=0,05)$ perlakuan interaksi antara lama fermentasi tempe dan penambahan bahan penstabil carboxymethyl cellulose (CMC).
Nilai $\mathrm{pH}$ terendah diperoleh dari kombinasi lama fermentasi tempe 36 dan penambahan CMC $0.25 \%$ yaitu 6,5 dan berbeda sangat nyata dengan perlakuan yang lain. $\mathrm{pH}$ 
tertinggi diperoleh dari perlakuan lama fermentasi 60 jam dan penambahan $\quad \mathrm{CMC} \quad 0,5 \%$ mempunyai $\mathrm{pH}$ 6,98. Secara umum $\mathrm{pH}$ susu tempe hasil penelitian ini adalah 6 , dan $\mathrm{pH}$ susu tempe dipengaruhi oleh $\mathrm{pH}$ tempe selama proses fermentasi. Steinkraus et al. (1960) dalam Nouts, M. J. R., J. L. Kiers. 2005 menyatakan perubahan yang terjadi selama fermentasi tempe antara lain peningkatan $\mathrm{pH}$ dari 5.0 menjadi 7.6. Peningkatan $\mathrm{pH}$ ini terjadi akibat pertumbuhan kapang yang cepat. Tempe yang berkualitas baik memiliki $\mathrm{pH}$ pada kisaran 6.3 hingga 6.5

\section{Tabel 2. Rata-rata pH Susu Tempe Perlakuan Kombinasi Lama Fermentasi Tempe dan Konsentrasi Penambahan Carboxymethyl cellulose (CMC)}

\begin{tabular}{|c|c|c|}
\hline $\begin{array}{c}\text { Perlakuan Lama Fermentasai Tempe } \\
\text { (jam) dan Konsentrasi CMC (\%) }\end{array}$ & Rata-rata pH & Notasi \\
\hline 36 jam, 0,25\% & 6,540 & $\mathrm{a}$ \\
36 jam, 0,5\% & 6,633 & $\mathrm{~b}$ \\
48 jam, 0,25\% & 6,717 & $\mathrm{c}$ \\
48 jam, 0,5\% & 6,750 & $\mathrm{~d}$ \\
60 jam, 0,25\% & 6,767 & $\mathrm{~d}$ \\
60 jam, 0,5\% & 6,983 & $\mathrm{~d}$ \\
\hline BNT 5\% & \multicolumn{2}{|c|}{0,032528} \\
\hline
\end{tabular}

Keterangan : Angka yang diikuti huruf yang sama, tidak berbeda nyata pada BNT 5\%

\section{Organoletik}

Proses

menyebabkan

keseluruhan terhadap sifat kedelai menjadi tempe, sehingga menghasilkan sifat tempe yang khas. Perbedaan waktu fermentasi tempe akan mempengaruhi karakteristik organoleptik susu tempe yang dihasilkan. Menurut Nouts, M. J. R., dan J. L. Kiers. (2005) selama masa fermentasi tempe terjadi perubahan keseluruhan dari kedelai, pembentukan rasa dan aroma yang lezat, dan perubahan bentuk dan tekstur tempe yang khas. Proses inkubasi tempe berlangsung pada 
24-36 jam suhu $30^{\circ} \mathrm{C}$ atau 48-72 penambahan carboxymethyl jam suhu $25^{\circ} \mathrm{C}$.

cellulose (CMC) antara 3.70

Kesukaan Rasa (cukup suka) sampai 5.15 (suka). Hasil uji organoleptik perlakuan lama fermentasi tempe menyajikan bahwa rata-rata kesukaan panelis terhadap rasa dari kombinasi perlakuan lama fermentasi tempe dan konsentrasi

Berdasarkan uji Friedman
perlakuan lama fermentasi tempe
dan penambahan bahan penstabil CMC berpengaruh nyata terhadap kesukaan rasa susu tempe.

\section{fermentasi tempe dan konsentrasi}

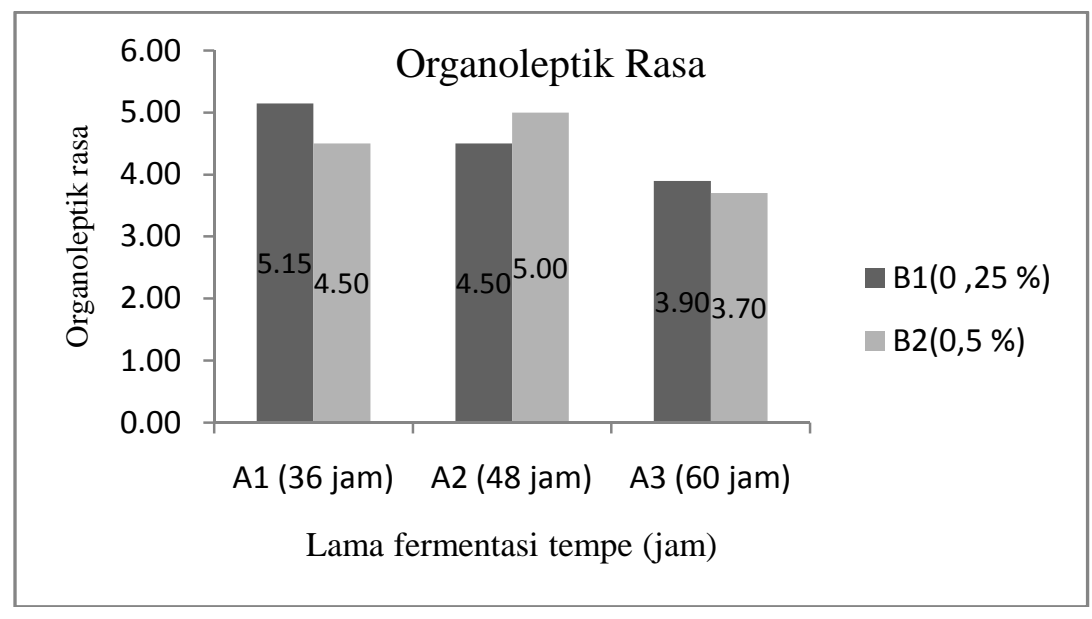

Keterangan

B1 = konsentrasi penambahan carboxymethyl cellulose $(\mathrm{CMC}) \quad 0,25 \%$

$\mathrm{B} 2=$ konsentrasi penambahan carboxymethyl cellulose $(\mathrm{CMC}) \quad 0,5 \%$

\section{Gambar 4. Rata-rata Kesukaan Rasa Susu Tempe}

Rata-rata nilai kesukaan carboxymethyl cellulose (CMC) 0.5 panelis terhadap rasa susu tempe \%, sedangkan nilai tertinggi sebesar mempunyai nilai terendah sebesar 5.15 (suka) didapatkan dari 3.70 (cukup suka) dari kombinasi kombinasi perlakuan lama perlakuan lama fermentasi tempe 60 fermentasi tempe 36 jam dan jam dan konsentrasi penambahan penambahan CMC $0.25 \%$. 
Susu tempe pada lama Warna fermentasi tempe 60 jam dan penambahan $0.5 \%$ mempunyai tingkat kesukaan yang rendah. Setelah 48 jam proses fermentasi ini. Panelis lebih menyukai susu tempe pada lama fermentasi tempe 36 jam dan konsentrasi penambahan carboxymethyl cellulose (CMC) $0.25 \%$. Perlakuan ini menghasilkan rasa yang cukup enak panelis menganggap bahwa rasa pada perlakuan ini sangat menyegarkan jika diminum.

Rerata kesukaan panelis terhadap warna susu tempe yang berkisar antara 4.40 (cukup suka) sampai 4.95 (suka). Hasil uji friedman menunjukkan bahwa hubungan antara perlakuan lama fermentasi tempe dan konsentrasi penambahan cellulose (CMC) berpengaruh nyata terhadap organoleptik warna susu tempe.

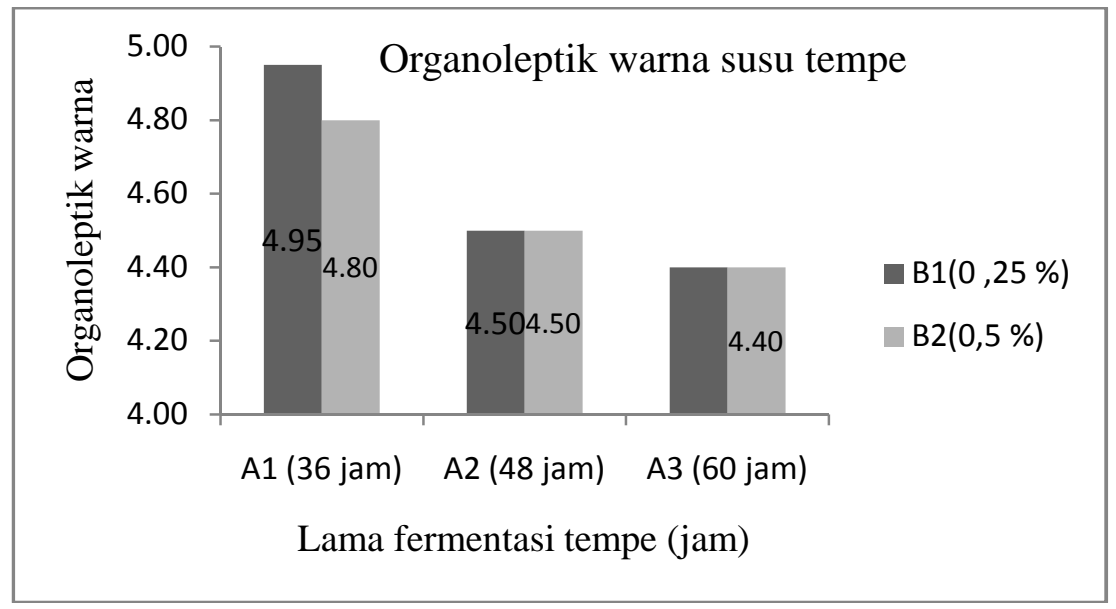

Keterangan

B1 = konsentrasi penambahan carboxymethyl cellulose (CMC) $0,25 \%$ $\mathrm{B} 2=$ konsentrasi penambahan carboxymethyl cellulose $(\mathrm{CMC}) \quad 0,5 \%$

Gambar 5. Rata-rata Kesukaan Warna Susu Tempe 
Kombinasi lama fermentasi tempe 36 jam dan konsentrasi penambahan cellulose (CMC) carboxymethyl memberikan nilai kesukan susu tempe tertinggi. Semakin lama fermentasi tempe dan konsentrasi penambahan carboxymethyl cellulose (CMC) yang meningkat, kesukaan panelis terhadap susu tempe semakin menurun.

Perlakuan lama fermentasi tempe dan konsentrasi penambahan carboxymethyl cellulose (CMC) yang meningkat menyebabkan warna kekeruhan pada produk yang dihasilkan. Menurut Prilestari (2001), penggunaan CMC sebesar $0,3 \%$ dari volume susu akan memberikan kualitas optimum ditinjau dari $\mathrm{pH}$, keasaman, overrun dan mutu organoleptik yogurt beku.

\section{Aroma}

Rerata kesukaan panelis terhadap aroma susu tempe yang berkisar antara 4.30 (cukup suka) sampai 4.80 (suka). Hasil uji friedman menunjukkan kombinasi perlakuan lama fermentasi tempe dan konsentrasi penambahan carboxymethyl cellulose (CMC) memberikan pengaruh nyata terhadap kesukaan aroma dari produk susu tempe yang dihasilkan. Rerata kesukaan panelis terhadap aroma susu tempe dapat dilihat pada Gambar 6.

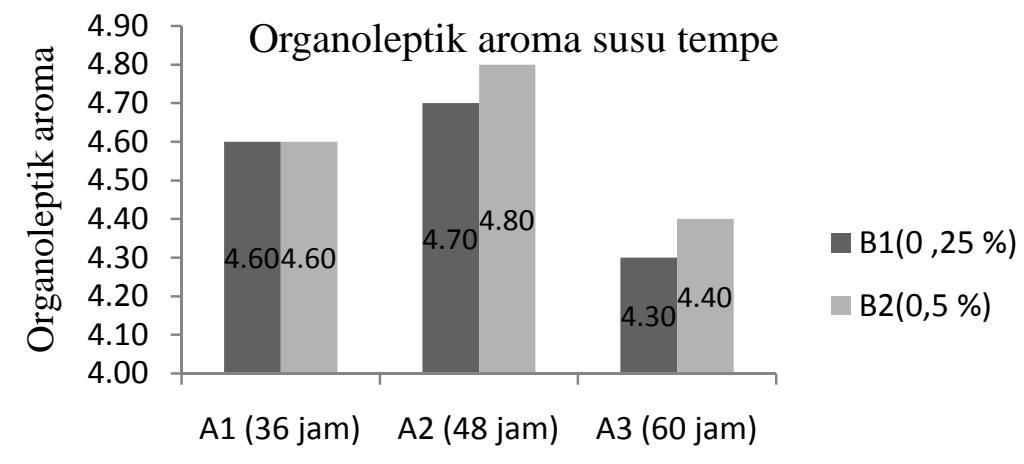

Lama fermentasi tempe (jam)

Keterangan

B1 = Penambahan bahan penstabil carboxymethyl cellulose (CMC) $0,25 \%$

$\mathrm{B} 2=$ Penambahan bahan penstabil carboxymethyl cellulose $(\mathrm{CMC}) \quad 0,5 \%$

\section{Gambar 6. Rata-rata Kesukaan Aroma Susu Tempe}


Berdasarkan Gambar 6. warna 4,50 (suka) dan aroma 4,70 kombinasi lama fermentasi tempe (suka).

48 jam penambahan bahan penstabil carboxymethyl cellulose (CMC) $0.5 \%$ memberikan nilai kesukan susu tempe tertinggi. Kombinasi perlakuan ini cenderung disukai panelis dimungkinkan, karena lama fermentasi tempe 48 jam menghasilkan rasa dan aroma tempe yang enak, sehingga susu yang dihasilkan mempunyai aroma khas, dan proposi bahan penstabil carboxymethyl cellulose (CMC) 0.5 $\%$ dianggap cukup baik.

\section{Uji Indeks Efektivitas}

Penentuan perlakuan terbaik lama fermentasi tempe dan konsentrasi penambahan carboxymethyl cellulose (CMC) susu tempe dilakukan dengan menggunakan metode indeks efektivitas. Metode ini dilakukan pada parameter kadar protein, TPT dan $\mathrm{pH}$ serta uji organoleptik pada rasa, warna, aroma. Kombinasi perlakuan lama fermentasi tempe 48 jam dan konsentrasi penambahan carboxymethyl cellulose (CMC) $\quad 0,25 \%$ merupakan perlakuan terbaik dengan karakteristik yaitu kadar protein $1,34 \%$; total padatan terlarut 9, 67 (brix), $\mathrm{pH}$ 6,72 ; organoleptik rasa 4,50 (suka),

\section{KESIMPULAN}

1. Perlakuan kombinasi lama fermentasi tempe dan konsentrasi penambahan carboxymethyl cellulose (CMC) berpengaruh nyata terhadap TPT ( total padatan terlarut), $\mathrm{pH}$ dan organoleptik rasa, warna dan aroma susu tempe.

2. Berdasarkan Uji Indek Efektifitas didapatkan bahwa perlakuan terbaik adalah kombinasi lama fermentasi tempe 48 jam dan konsentrasi penambahan carboxymethyl cellulose (CMC) 0,25\% dengan karakteristik yaitu kadar protein $1,34 \%$; total padatan terlarut 9, 67 (brix), pH 6,72 ; organoleptik rasa 4,50 (suka), warna 4,50 (suka) dan aroma 4,70 (suka).

\section{DAFTAR PUSTAKA}

Anonim. 2008. info.www.tempeinfo.com Astawan, Made. 2009. Sehat dengan Hidangan Kacang dan Biji-bijian. Penerbit Swadaya. Depok.

De Reu, J.C., Ten Wolde, R.M., De Groot, J., Nouts, M. J. R., Rombouts, F. M. And Gruppen, H. 1995. Protein Hydrolysis during Soybean 
Fermentation Rhizopus oligosporus. Journal of Food Agriculture and Food Chemistry, 43, 2235-2239.

Imeson, A.1992. Thickening and Gelling Agents for Food. Blackie Academic \& Professional. New York.

Kasmidjo, R.B. 1996. Tempe : Mikrobiologi dan Biokimia Pengolahan serta

Pemanfaatannya. PAU

Pangan dan Gizi. UGM, Yogyakarta.

Nouts, M. J. R., J. L. Kiers. 2005. A review Tempe Fermentation, Innovation and Functionality : Update into the third Millenium. Journal of Applied Microbiology, 98, 789-805.

Prilestari, C.D. 2001. Pengaruh Penambahan CMC Sebagai Bahan Penstabil EmulsiTerhadap $\mathrm{pH}$, Keasaman, Overrun,

Kecepatan Meleleh Dan Mutu Organoleptik Yogurt Beku. Skripsi. Teknologi Hasil Ternak. Fakultas Peternakan.UniversitasBrawij aya. Malang

Subagio, A., Siti H., Wiwik, S. W., Unus, Mukhammad Fauzi, dan Bambang Herry. 2002. Kajian Sifat Fisikokimia dan
Organoleptik Hidrolisat Tempe Hasil Hidrolisis Protease. Jurnal Teknologi dan Industri Pangan, Vol.13, No. 3.

Susanto, Tri, Sawitri, Meita, Widaryanti, Eni. 1997. Research on the Utilization of Tempe as Raw Material In The Production of Milk and Tempe Sausage. In Sudarmadji, Suparno and Rahayu. Proceeding, International Tempe Symposium. July 13-15 1997.

Widowati, S . 2004. Tempe Dan Produk Turunannya : Pangan Fungsional Indigenous Indonesia. Dalam Prosiding Seminar Nasional Peningkatan Daya Saing Pangan Tradisional. Balai Besar Penelitian Dan Pengembangan Pascapanen Pertanian. Hal 220-228

Widowati, S.,Yuniar, M.E. Christina dan R. Holinesti. 2004. Analisis Kerusak an Produk tempe Kedelai. Lap MK Pengawetan Pangan. Program Studi Ilmu Pangan, Sekolah Pascasarjana, IPB 